\title{
Science Teachers' Attitudes towards Using ICT and Mobile Learning Technologies in Malaysian Schools
}

\author{
Mohammed Yousef Mai \\ Faculty of Education, Universiti Pendidikan Sultan Idris, 35900 Tanjong Malim, Perak Darul Ridzuan \\ dr.mohd.mai@gmail.com
}

\begin{abstract}
The use of ICT has resulted in new opportunities that mobile devices have transformed from a means of communication to tools for socialization, entertainment, work, and learning. The aim of this study is to determine the science teachers' attitudes towards ICT and using mobile learning in education. The research sample consists of (67) science teachers from different cities in Malaysia who studing for master in University Education Sultan Idris. A valid and reliable scale has been adapted from "Mobile Learning Survey" (Pollara, 2011) and "Information and Communication Technology Attitudes Questionnaire-IAQ" (Kubiatko \& Haláková, 2009; Mehra \& Far, 2013) was used as a data collection tool. The results indicate that; science teachers have positive attitudes toward using ICT and mobile learning in education. On the other hand, science teachers' attitudes towards mobile learning was predicted by their perception about ICT and their self-efficacy.
\end{abstract}

Keywords: Science teachers, ICT, mobile learning.

\section{Introduction}

The recent time is influenced by an intensive usage of information and communication technologies. These technologies influence the way that young people play, socialize, and communicate as well as the educational process and has led to fundamental changes in education. The integration of Information and Communications Technology (ICT) in classrooms has been a challenge for the educational systems that aim to cope with the needs and the demands of the 21st century (Kyriakidou, Chrisostomou, \& Banks, 1999; Yapici \& Hevedanli, 2012 ).

The Malaysian Ministry of Education (MOE) has introduced various initiatives to facilitate the adoption and diffusion of Information and Communication Technology (ICT). In line with the Vision 2020, Ministry of Education has draft ways to integrate ICT into the education system. The Malaysian government has invested millions of Ringgit for the usage of ICT in education (Rashid, 2011). The Malaysian Ministry of Education sees ICT as a means, not an end in itself. As such, all efforts are concentrated on developing new media as tools in the service of richer curricula, enhanced pedagogies, more effective organizational structures in schools, stronger links between schools and society, and the empowerment of disenfranchised learners. The concept of ICT in education, as seen by the Ministry of Education, includes systems that enable information gathering, management, manipulation, access, and communication in various forms. The Ministry has formulated three main policies for ICT in education (Chan \& Foong-Mae, 2002; Mohd Zaki M. et al., 2009):

1. ICT is for all students, meaning that ICT is used as an enabler to reduce the digital gap between the schools.

2. Emphasizes the role and function of ICT in education as a teaching and learning tool, as part of a subject as well as a subject by itself.

3. Emphasizes the use of ICT to increase productivity, efficiency and effectiveness of the management system such as the processing of official forms, timetable generation, management of information systems, lesson planning, financial management and the maintenance of inventories.

It is now recognized that learning occurs in different settings, and school is only one of them. The way that young people use digital technologies in out-of-school settings and the intensity with which digital technologies are being used has challenged the educational community to rethink the nature of learning in informal settings, and how informal learning can inform formal learning. Education today takes place in a much broader context than the confines of school walls or traditional curricula (Khaddage \& Knezek, 2013). 


\section{Theoretical Background}

Much discussion about technology and education has focused on the question of how technology facilitates teaching and learning. The potential benefits of using ICT in teaching and learning are immense. The use of ICT has greatly transformed the outcomes of teaching and learning experience in classrooms. It does not only supplement and/or complement teacher instructional processes, but also offers unlimited access to knowledge and information that is readily available through the internet, manipulate data, explore relationships, intentionally and actively process information, construct personal and socially shared meaning and reflect on the learning process. It also gives the students opportunities to examine a variety of viewpoints so they can construct their own knowledge of various concepts (Koç, 2005; Tam, 2000).

The educational potential of ICT is stressed in a variety of ways. For instance, the potential of ICT could be to present rich learning environments, allowing learners to adopt multiple perspectives on complex phenomena, to foster flexible knowledge construction in complex learning domains, and to cater for individual differences (Sang, Valcke, Braak, \& Tondeur, 2010). Students are more than ready to embrace technology in education. Today's students have grown up using digital technology. Surveys show that, of young people aged 12-17 (Look, 2005):

- Over $50 \%$ have their own blog or contribute to another blog or website

- Over $50 \%$ download music

- $90 \%$ use the internet to search for information for class assignments

- $80 \%$ are given internet assignments to complete at school

- $60 \%$ are using online dictionaries, encyclopedias and thesauruses

- Over $70 \%$ say that having access to the internet helps them earn better grades $\&$ be stronger students

Look (2005) cited that a review of 219 studies on the use of technology in education consistently found that students in technology rich environments experienced positive effects on achievement in all subject areas. The merits of ICT in education have been extolled in the literature. The use of ICT has been found to (Fu, 2013; Kubiatko \& Haláková, 2009; Look, 2005; Sim \& Theng, 2014):

1. Assist students in accessing digital information efficiently and effectively

2. Support student-centered and self-directed learning

3. Produce a creative learning environment

4. Promote collaborative learning in a distance-learning environment

5. Offer more opportunities to develop critical (higher-order) thinking skills

6. Support teaching by facilitating access to course content

7. ICT offers students more time to explore beyond the knowledge allowing them to understand better the scientific concepts.

8. ICT enhances the effectiveness of information presentation and stimulates students' interest.

9. ICT can improve the quality of education.

10. The use of multimedia approach had been successful in generating conceptual understanding.

11. The use of interactive multimedia software motivates students and leads to improved performance.

12. Using ICT increase the students' attitudes.

Further, research studies showed that ICT motivate student learning, there are a lot of assumptions that students are interested in using ICT; they found it more pleasant, more appealing, and more motivating to study with ICT tools than by traditional means (Kubiatko \& Haláková, 2009). Multimedia and technology have proven helpful in engaging students in learning about subjects, in exploring ways to present their learning, and in helping students control their learning (Taylor \& Parsons, 2011). In sum, the use of ICT also changes the teaching and learning relationship.

One of the technologies that teachers and students can use in learning process is the "Mobile technology". Mobile technology is changing the way we live and it is beginning to change the way we learn, mobile technology have transformed from a means of communication to tools for socialization, entertainment, work, and learning. Statistics show that over 6 billion people have access to a connected mobile device and for every one person who accesses the internet from a computer two do so from a mobile device (Tamhane, Khan, Tribhuwan, Burke, \& Take, 2015). According to the International 
Telecommunication Union 2014, the number of mobile-cellular subscriptions worldwide is approaching the number of people on earth. Mobile cellular subscriptions will reach almost 7 billion by end 2014, corresponding to a penetration rate of $96 \%$. More than half of these (3.6 billion subscriptions) will be in the Asia-Pacific region (Union, 2014).

Mobile learning involves the use of mobile technology, either alone or in combination with other information and communication technology (ICT), to enable learning anytime and anywhere. Learning can unfold in a variety of ways: people can use mobile devices to access educational resources, connect with others, or create content, both inside and outside classrooms. Mobile learning also encompasses efforts to support broad educational goals such as the effective administration of school systems and improved communication between schools and families (Tamhane et al., 2015). The concept of mobile education or mobile learning is still emerging and still unclear. Early approaches at defining mobile learning focused on technology, for example, it can be considered as any learning and teaching activity that is possible through mobile tools or in settings where mobile equipment is available. Caudill (2007) cite multiple definitions of $\mathrm{m}$ Learning, including:

1. The point at which mobile computing and e-Learning intersect to produce an anytime, anywhere learning experience.

2. Mobile learning is a form of education whose site of production, circulation, and consumption is the network.

3. M-learning is as a process of coming to know, by which learners in cooperation with their peers and teachers, construct transiently stable interpretations of their world.

4. Mobile Learning- (M-Learning) The process of using a mobile device to access and study learning materials and to communicate with fellow students, instructors or institutions. Mobile learning can be done anytime, anywhere (Pollara, 2011).

Researchers suggested that there are three ways in which learning can be considered mobile: (1) learning is mobile in terms of space; (2) in different areas of life; and (3) with respect to time. It is clear that mobile learning systems should be capable of delivering educational content to learners anytime and anywhere they need it (Aderinoye, Ojokheta, \& Olojede, 2007). In general, we can conclude that mobile learning is the use of any mobile or wireless device for learning indoor or outdoor. It is any service or facility that supplies a learner with electronic learning materials that aids their acquisition of knowledge, regardless of location and time.

Mobile learning is a relatively new phenomenon with its theoretical basis still under development. Researchers have begun to analyze more specific characteristics of mobile learning, including how mobile learning can support learning opportunities, the types of learning and learning activities that can be supported, and the various contexts in which mobile learning can take place. According to Sharples (2006), key characteristics of mobile learning that emerged were as follows:

1. Enables knowledge building to take place in different contexts.

2. Provides the ability to gather data unique to the current location, environment, and time (real and situated).

3. Enables learners construct their own understanding (customized to the individual path of investigation).

4. Changes the pattern of learning or the work activity (supports interactivity).

5. Supports the use of mobile learning applications which are mediating tools and can be used in conjunction with other learning tools.

6. Goes beyond time and space in which learning becomes part of a greater whole.

From a pedagogical perspective, mobile learning will serve a whole new highly mobile segment of society, a reality that could very well enhance the flexibility of the educational process (Aderinoye et al., 2007). Peters (2007) say that characteristics of mobile learning must include:

1. Urgency of learning needs

2. Initiative of knowledge acquisition

3. Mobility of learning setting

4. Interactivity of the learning process

5. 'Situatedness' of instructional activities

6. Integration of instructional content 
Given that $\mathrm{m}$-Learning is a discipline unto itself, there are certain advantages provided in a m-Learning environment that are not present in other kinds of e-Learning. The primary advantage of m-Learning is to provide truly anytime, anyplace learning. What this means for the learner is that they are no longer constrained by static resources. In addition to being able to access resources from anywhere with a mobile device, this ease of transport has other advantages. Perhaps most notably, mobile devices provide users with an interface to their content that is both personalized and secure (Caudill, 2007). According to Lim, Fadzil, and Mansor (2011), the general objectives of mobile learning are to:

1. Enhance the blend of the learning modes;

2. Increase the flexibility of learning offered to learners; and

3. Encourage and support ubiquitous learning (just in time, anytime, anywhere) via mobile technologies.

4. In a report of more than 25 handheld learning projects, Shuler (2009) found that the report highlights five opportunities to seize mobile learning's unique attributes to improve education. Those key opportunities for mobile learning include:

5. Encourage "anywhere, anytime " learning: Students can gather and process information outside the classroom to learn in a real-world context.

6. Reach underserved children: The low cost of a mobile device makes it accessible to low-income families and can help advance digital equity.

7. Improve 21 st-century social interactions: Mobile technologies can promote and foster communication and collaboration; all important skills of the 21 st century.

8. Fit with learning environments: Mobile devices can fit easily into many learning environments and eliminate the barriers associated with large devices.

9. Enable a personalized learning experience: Mobile devices allow differentiated instruction for diverse learners who can learn at their own pace.

Shuler (2009) remarked that mobile devices might be used to capitalize on the personalization capabilities of the devices that make learning more accessible. Mobile devices have bridged learning in school, afterschool, and home environments. Similarly, Shih and Mills (2007) and Pollara (2011) agree that the potential uses of Mobile learing in the classroom can do more than foster communication and aid in the exchange of information. They identify several potential advantages of mobile learning.

1. Mobile learning helps learners improve their literacy and numeracy skills and to recognize their existing abilities

2. Mobile learning helps learners to increase their understanding of the material/curriculum content.

3. Mobile learning may act as a good assessment tool for the students to identify areas where they need assistance and support

4. Mobile learning can be used to encourage both independent and collaborative learning experiences

5. Mobile learning helps to combat resistance to the use of ICT and can help bridge the gap between mobile phone literacy and ICT literacy.

6. Mobile learning helps to remove some of the formality from the learning experience and engages reluctant learners to express themselves and their ideas in a manner that is most comfortable to them.

7. Mobile learning helps learners to remain more focused for longer periods

8. Mobile learning helps to raise self-esteem/self-confidence

9. Mobile learning helps to increase students' motivation.

10. Mobile devices are becoming increasingly less expensive than purchasing textbooks, desktop, or laptop computers.

11. A student may use his or her mobile device to podcast, study using virtual flashcards, access the internet, connect to social media, read a poem, respond to a question posed by the teacher, post a comment, blog, or use the device as a calculator.

12. Games for mobile phones have the potential to support both cognitive and socio-affective learning while aiding in the development of strategic thinking, planning, communication, application of numbers, negotiating skills, group decision making and data handling. 
Those advantages are supporting the results of some studies that integrating Mlearning with sound curriculum can contribute to increased student engagement, collaboration, productivity, technology competency, innovation, and critical thinking (Chou, Block, \& Jesness, 2012). The study done by UNESCO (2012) has shown that mobile learning projects in South Africa have been used to improve teaching system especially teaching biology subjects. Furthermore the study conducted by Utulu and Alonge (2012) in Nigeria revealed that mobile phones were used by students for communicating with lecturer in charge of the course, collect data (recordings), sending emails to lecturers, access Online Public Access Catalogue and share knowledge. Also a study by Kajumbula (2009) in Makerere University-Uganda found that mobile phones were used by students for learning and teaching; for example, students can know whether their marks are missing, dates for tutorials, venues and meeting times with research supervisors.

Research has shown that teachers still resist the integration of new technology into the classroom. There are many factors affect the teachers' usage of new technology especially mobile learning. Researchers proposed those factors as the following (Kathryn MacCallum, Lynn Jeffrey, \& Kinshuk, 2014):

1. Teachers' beliefs about the perceived value of the new technology "usefulness" and the perceived effort needed to learn to use the new technology "ease of use".

2. Teachers' skills to use and integrate digital technology into their teaching "digital literacy".

3. Teachers' self-efficacy beliefs pertaining to their own level of competence and their attitudes towards technology adoption.

4. ICT anxiety is considered as the tendency of a teacher to experience a level of uneasiness over his/her impending use of ICT.

The results on many studies indicated the importance of these factors in the acceptance of mobile learning.

The success of any initiatives to integrate ICT in classroom life depends strongly upon the support and attitudes of teachers involved, especially new teachers (Kyriakidou et al., 1999; Teo, 2008). Teachers' attitudes to and perceptions of technology use affect their technology use in instruction; guide the decisions teachers make and actions they take in the classroom. Those factors are important in motivating and encouraging a teacher to use technology in the classroom (Gilakjani, Leong, \& Ismail, 2013). The results of those studies support the evidence that teachers' beliefs have an influence on the way they organized their classrooms, interacted with students, and how they act in the classroom (Fu, 2013; Palak \& Walls, 2009). Palak and Walls (2009) mentioned that teachers who effectively integrate technology move toward student-centred instructional practices, and this in turn suggests a shift in teachers' beliefs as teachers experience new patterns of teaching and learning.

\section{Purpose of the Study}

The success of student learning with ICT will depend largely on the teachers' abilities, perceptions, and their willingness to embrace the technology (Teo, 2006). Teachers' attitudes and perceptions towards ICT is a very important factor that educators ought to consider in implementing mobile learning in classroom and it is a major predictor for future ICT use in the classroom (Teo, 2008). Other factors such as digital literacy, teachers' self-efficacy, and ICT anxiety are crucial for the usage of ICT as well as mobile learning. Therefore, the major purpose of this study is to examine science teachers' ICT attitudes and perceptions towards using ICT and mobile learning in teaching and learning as well as the factors affect the use of mobile learning. In particular, the following research questions will be addressed:

1. What are teachers' attitudes and perceptions toward ICT and mobile learning application in education?

2. How will the variables of the perceived attitudes and perceptions towards ICT and mobile learning, use of mobile and self-efficacy influence the perceptions and behaviour intention of science teachers' attitudes to adopt mobile learning?

\section{Method and Research Design}

This research is a descriptive in nature; its key purpose is a description of the state of affairs, as it exists at present. Surveys are concerned with describing, recording, analyzing and interpreting conditions that either exist or existed (Kothari, 2004). Therefore, qualitative data were obtained through a survey conducted with science teachers, the gathered data were analyzed using both descriptive and inferential statistics. 


\section{Participants}

The research sample consist of 67 science teachers who teaching science from two cities in Malaysia in the academic year of 2014-2015, they were invited to participate in the survey via email that included a link to the web-based survey. The male teachers $(n=23)$ form $34.3 \%$ of the sample while the female teachers $(n=44)$ form $65.7 \%$ of the sample.

\section{The Instrument}

In order to investigate the science teachers' perceptions and attitudes towards ICT and mobile learning in education, the researcher adapted two instruments.

"Teachers' attitudes and beliefs about ICT" has been adapted from (Jimoyiannis \& Komis, 2006) and from Mehra and Far (2013). The adapted questionnaire was a Likert-type scale containing 28 items that presented statements of perceptions and attitudes toward ICT. Every item in the questionnaire is 5 Likert scale. Likert scale question comprised five points ranking following: "strongly agree" (5 points), "agree" (4 points), "neutral" (3 points), "disagree" (2 points), "strongly disagree" (1 point). Several questions were constructed negatively. The evaluation of them was in reverse order. The scale consists of two dimensions, namely attitudes towards ICT in instruction (12 items) and perceptions/beliefs about the role of ICT in education (16 items). The results of Split-half reliability test and Cronbach's Alpha internal consistency coefficient for the sub-categories indicate that "Attitudes towards ICT in instruction" has Split-half reliability test of 0.757 and Cronbach's alpha of 0.83 . On the other hand, "Beliefs about the role of ICT in education" has split-half reliability test of 0.969 and Cronbach's alpha of 0.90 . This means that the instrument has a good reliability and can be used to measure the science teachers' ICT attitudes and perceptions towards using ICT.

"Mobile Learning Survey" developed by Pollara (2011) has been adapted to survey teachers' usage, cababilities and perceptions about mlearning. The adapted questionnaire was a Likert-type scale containing 34 items that presented statements of perceptions and current educational use of mlearning. The instrument consists of two sections; the first section divided into three sub-scale: prior knowledge (items 1-5), teachers' self-efficacy (items 6-10) and Ease of Use (items 11-18), the items in this section are 3 Likert scale (usually, sometimes, never). The second section of the instruments contains 16 questions related to perception about Mleaarning.. Every item in the second section is 5 Likert scale. Likert scale question comprised five points ranking following: "strongly agree" (5 points), "agree" (4 points), "neutral" (3 points), "disagree" (2 points), "strongly disagree" (1 point). Cronbach's alpha, the measure of reliability, was calculated for the scales and subscales for items measured on the five-point Likert scale. The overall scale had an alpha of 0.864 . The instrument has a good reliability and can be used to measure the science teachers' perceptions towards mlearning.

\section{Research Results}

The research's survey asked science teachers to report their use of mobile devices for various educational tasks, their selfefficacy and thier attitudes towards ICT and mobile learning. Teachers were able to respond to as many of the questions that they believed applied to their prior use of a mobile device. Table (1) includes the means and standard deviations about science teachers prior knowledge, self-efficacy, use of mobile devices and attitudes.

The results show that science teachers have a high level of knowledge $(82.8 \%)$ about using mobile learning and ICT in the learning process $(\mathrm{M}=2.484, \mathrm{SD}=0.365)$. They also highly evaluate $(77 \%)$ their self-efficacy in using mlearning $(\mathrm{M}=$ $2.31, S D=0.438)$ and their frequent use of mlearning and its application in the learning process $(M=2.427, S D=0.398)$, the percent of using mlearning is $80.9 \%$.

In the next section of the survey, teachers were asked about their attitudes and perceptions with regard to ICT and mobile learning and mobile device use in the classroom. Means and standard deviations were calculated for all items, means above 2.5 indicate a positive response, 1.5-2.4 neutral while means below 1.5 indicate a negative response to the question. The results in table 1 show that science teachers have positive attitudes about Mlearning $(M=3.436, S D=0.685)$ and about ICT $(M=3.42, S D=0.352)$. They also have good and positive perceptions about ICT application in instruction ( $M=$ $3.596, \mathrm{SD}=0.446)$. 
Those results indicate that science teachers believe about the importance of using ICT and mobile in education and they assert the usefulness of applying it in the teaching and learning process.

The second aim of this research is to investigate the effectiveness of the perceived attitudes and perceptions towards ICT, use of mobile, and self-efficacy in influencing science teachers' attitudes towards mobile learning. Therefore, a multiple linear regression analysis was conducted and a full model entry was employed to regress all predictor variables onto the dependent variable simultaneously. Table 2 displays the correlations between the variables.

Each variable has a positive significant correlation with each other variable with no any Multicollinearity. To get more information about the goodness of fit of a model, the results about $R$ Square is presented in Table 3 . In this case the $R^{2}$ of 0.393 indicates that $39.3 \%$ of the variation in science teachers' attitudes towards mlearning is explained by the regression variables. The adjusted $R^{2}$ value of 0.354 indicates that a good percent of the variability in science teachers' attitudes towards mlearning could be predicted by their perceptions towards ICT, use of mobile learning, and self-efficacy.

For more information about the model, Table 4 shows the regression ANOVA, which tests for a linear relationship between the variables. The results in the ANOVA Table $(F(4,62)=10.044, p<.001)$ indicate that the value of $F$ is significant beyond the 0.01 level. The full model $R^{2}$ was significantly greater than zero, $R^{2}=40.7 \%$.

On the second step all of the predictors were entered simultaneously, resulting the "Coefficients", that provides the estimates of the regression coefficients (table 5).

Analysis of regression coefficients (Table 5 ) indicated that science teachers' attitudes towards mobile learning was predicted by their perception about ICT (Beta $=0.8, p<.01$ ), and their self-efficacy (Beta $=0.4, p<.01$ ). It is clear that those variables predicted significantly $39.3 \%$ of the variance. The other variables (prior knowledge and frequent use of mobile) are not a significant predictor. The overall model fit was $R^{2}=0.393$. Thus, the positive perceptions and the highest self-efficacy increase science teachers' attitudes towards using mobile learning in science classroom.

\section{DISCUSSION}

The research's survey asked science teachers to report their use of mobile devices for various educational tasks, their selfefficacy and thier attitudes towards ICT and mobile learning. The results show that science teachers have a high level of knowledge about using mobile learning and ICT in the learning process. They also have a high level of self-efficacy in using mlearning and of using mlearning and its application in the learning process. One the other hand, science teachers have positive attitudes and perceptions about Mlearning and about ICT. Each variable has a positive significant correlation with each other variables, the adjusted $R^{2}$ value indicates that a good percent of the variability in science teachers' attitudes towards mlearning could be predicted by the independent variables. For more specification, science teachers' attitudes towards mobile learning was predicted by their perception about ICT and their self-efficacy.

\section{REFERENCES}

[1] Aderinoye, R. A., Ojokheta, K. O., \& Olojede, A. A. (2007). Integrating Mobile Learning into Nomadic Education Programmes in Nigeria: Issues and perspectives. International Review of Research in Open and Distance Learning, 8(2).

[2] Caudill, Jason G. (2007). The Growth of m-Learning and the Growth of Mobile Computing: Parallel developments. International Review of Research in Open and Distance Learning, 8(2).

[3] Chan, By, \& Foong-Mae. (2002). ICT in Malaysian Schools: Policy and Strategies. Retrieved 2/6/2014, from http://gauge.ugakugei.ac.jp/

[4] Chou, Chientzu Candace, Block, Lanise, \& Jesness, Renee. (2012). A case study of mobile learning pilot project in K-12 schools. Journal of Educational Technology Development and Exchange, 5(2), 11-26.

[5] Fu, Jo Shan. (2013). ICT in Education: A Critical Literature Review and Its Implications. International Journal of Education and Development using Information and Communication Technology (IJEDICT), 9(1), 112-125.

[6] Gilakjani, Abbas Pourhosein, Leong, Lai-Mei, \& Ismail, Hairul Nizam. (2013). Teachers' Use of Technology and Constructivism. I.J.Modern Education and Computer Science, 4, 49-63. doi: 10.5815/ijmecs.2013.04.07 
[7] Jimoyiannis, Athanassios, \& Komis, Vassilis. (2006). Exploring secondary education teachers' attitudes and beliefs towards ICT adoption in education. Themes in Education 7(2), 181-204.

[8] Kajumbula, Richard. (2009). Challenges In Implementing A Mobile Short Messaging Service (SMS) Program To Support Distance Education Students At Makerere University, Uganda. Paper presented at the the International Council for Distance Education Conference Maastricht, The Netherlands. www.ou.nl/Docs/Campagnes/ICDE2009/Papers/Final_Paper_316.doc

[9] Kathryn MacCallum, Lynn Jeffrey, \& Kinshuk. (2014). Factors impacting teachers' adoption of mobile learning. Journal of Information Technology Education, 13.

[10] Khaddage, Ferial, \& Knezek, Gerald. (2013). Introducing a Mobile Learning Attitude Scale for Higher Education. Paper presented at the $\mathrm{X}$ World Conference on Computers in Education, Torun, Poland.

[11] Koç, Mustafa. (2005). Implications of Learning Theories for Effective Technology Integration and Pre-service Teacher Training: A Critical Literature Review. Journal of Turkish Science Education, 2(1), 2-18.

[12] Kothari, C. R. (2004). Research Methodology: Methods and Techniques: New Age International Publishers.

[13] Kubiatko, M. , \& Haláková, Z. . (2009). Slovak High School Students' Attitudes to ICT Using in Biology Lesson. Computers in Human Behavior 25, 743-748.

[14] Kyriakidou, Maria, Chrisostomou, Charalambos, \& Banks, Frank. (1999). Primary Teachers' Attitude to the Use of ICT: a comparative study between Cyprus and the UK. Paper presented at the the European Conference on Educational Research, Lahti, Finland

[15] Lim, Tina, Fadzil, Mansor, \& Mansor, Norziati. (2011). Mobile Learning via SMS at Open University Malaysia: Equitable, Effective, and Sustainable. . International Review of Research in Open and Distance Learning, 12(2), 122-137.

[16] Look, D. (2005). Discussion Paper: Impact of Technology on Education: PUSD Excellence Committee.

[17] Mehra, Vandana, \& Far, Ziba Nikkhah. (2013). A Scale To Measure University Teachers' Attitude Towards ICT. International Journal of Teacher Educational Research (IJTER) 2(7).

[18] Mohd Zaki M., Faizal M.A., Erman H., Nazrulazhar B., A., Nor Azman M., \& Y., Asrul Nadi. (2009). ICT Development In Malaysia. Paper presented at the Seminar on Information Technology 2009 (SemiT 2009)

[19] Palak, Deniz, \& Walls, Richard T. (2009). Teachers' beliefs and technology practices: A mixed-methods approach. Journal of Research on Technology in Education, 41(4), 417-441.

[20] Pollara, Pamela. (2011). Mobile Learning In Higher Education: A Glimpse And A Comparison Of Student And Faculty Readiness, Attitudes And Perceptions. (PhD), Graduate Faculty of the Louisiana State University and Agricultural and Mechanical College.

[21] Rashid, Adnan Abd. (2011). The Utilization of Information and Communication Technology among Islamic Secondary School Teachers in Malaysia. Sosiohumanika, 4(2), 145-158.

[22] Sang, Guoyuan, Valcke, Martin, Braak, Johan van, \& Tondeur, Jo. (2010). Student teachers' thinking processes and ICT integration: Predictors of prospective teaching behaviors with educational technology. Computer and Education, 54, 103112.

[23] Sharples, Mike. (2006). Big Issues in Mobile Learning. Report of a workshop by the Kaleidoscope Network of Excellence (M. L. Initiative, Trans.). NOTTINGHAM: UNIVERSITY OF NOTTINGHAM.

[24] Shih, Yuhsun Edward, \& Mills, Dennis. (2007). Setting the New Standard with Mobile Computing in Online Learning. International Review of Research in Open and Distance Learning, 8(2).

[25] Shuler, Carly. (2009). Pockets of Potential: Using Mobile Technologies to Promote Children's Learning. New York: The Joan Ganz Cooney Center at Sesame Workshop.

[26] Sim, Janice CH, \& Theng, Lau Bee. (2014). Teachers' perceptions of the use of ICT as an instructional tool in Mathematics and Science. $\quad$ Retrieved 2/6/2014, 2014, from https:/www.google.com.my/url?sa=t\&rct=j\&q=\&esrc=s\&source=web\&cd=1\&cad=rja\&uact=8\&ved=0CC0QFjAA\&url=http\% 3 A\%2F\%2Fictl.intimal.edu.my\%2Fict|2007\%2Fproceeding\%2FFull_Paper\%2F1A-03- 
Paper\%252069\%2520(Malaysia).pdf\&ei=R5CMU9aeCZPn8AX2vIDwDQ\&usg=AFQjCNFaQnzrsHB8dbqt8fVJplqtqd9W4w \&sig2=FlySeO2caUClvp80cVwHNg

[27] Tam, Maureen. (2000). Constructivism, Instructional Design, and Technology: Implications for Transforming Distance Learning. Educational Technology \& Society 3(2).

[28] Tamhane, K.D., Khan, Wasim T., Tribhuwan, Sagar R., Burke, Akshay P., \& Take, Sachin B. (2015). Mobile Learning Application. International Journal of Scientific and Research Publications, 5(3).

[29] Taylor, L. , \& Parsons, J. . (2011). Improving Student Engagement. Current Issues in Education, 14(1), 1-32.

[30] Teo, Timothy. (2008). Pre-service teachers' attitudes towards computer use: A Singapore survey. Australasian Journal of Educational Technology, 24(4), 413-424.

[31] UNESCO. (2012). Mobile learning for teachers in Africa and the Middle East: Exploring the potentials of mobile technologies to support teachers and improve practices. France: the United Nations Educational, Scientific and Cultural Organization.

[32] Union, International Telecommunication. (2014). The world in 2014, ICT Facts and Figures. Switzerland, Geneva: ICT Data and Statistics Division.

[33] Utulu, Samuel C., \& Alonge, Ayodele. (2012). Use of mobile phones for project based learning by undergraduate students of Nigerian private universities. International Journal of Education and Development using Information and Communication Technology (IJEDICT), 8(1), 4-15.

[34] Yapici, I. Umit, \& Hevedanli, Murat. (2012 ). Pre-Service Biology Teachers' Attitudes towards ICT Using In Biology Teaching. Procedia - Social and Behavioral Sciences 64633 - 638. doi: 10.1016/j.sbspro.2012.11.074

Table 1. Basic Descriptive Statistics

\begin{tabular}{|l|l|l|l|}
\hline & Mean & Mean \% & Std.Dev. \\
\hline Prior Knowledge & 2.484 & $82.8 \%$ & 0.365 \\
\hline Self-efficacy & 2.310 & $77.0 \%$ & 0.438 \\
\hline Use of Mobile & 2.427 & $80.9 \%$ & 0.398 \\
\hline attitudes ML & 3.436 & $68.7 \%$ & 0.685 \\
\hline Attitudes ICT & 3.420 & $68.4 \%$ & 0.352 \\
\hline perception ICT & 3.596 & $71.9 \%$ & 0.446 \\
\hline
\end{tabular}

Table 2. Correlations Between Predictor Variables

\begin{tabular}{|l|l|l|l|l|l|}
\hline & Prior Knowledge & Self-efficacy & Use of Mobile & attitudes ML & perception ICT \\
\hline Prior Knowledge & 1 & $.335^{\star}$ & $.287^{\star}$ & $.296^{*}$ & $.321^{*}$ \\
\hline Self-efficacy & $.335^{\star}$ & 1 & $.383^{\star}$ & $.452^{\star}$ & $.391^{\star}$ \\
\hline Use of Mobile & $.287^{\star}$ & $.383^{*}$ & 1 & $.398^{\star}$ & $.489^{\star}$ \\
\hline attitudes ML & $.296^{\star}$ & $.452^{*}$ & $.398^{\star}$ & 1 & $.579^{\star}$ \\
\hline perception ICT & $.321^{\star}$ & $.391^{*}$ & $.489^{\star}$ & $.579^{\star}$ & 1 \\
\hline
\end{tabular}

${ }^{*}$ Correlation is significant at the 0.01 level (2-tailed).

Table 3. Model Summary 


\begin{tabular}{|l|l|l|l|l|}
\hline Model & R & R Square & Adjusted R Square & Std. Error of the Estimate \\
\hline 1 & 0.627 & 0.393 & 0.354 & 0.549 \\
\hline
\end{tabular}

Table 4. The regression ANOVA

\begin{tabular}{|l|l|l|l|l|l|}
\hline Model & Sum of Squares & df & Mean Square & F & Sig. \\
\hline Regression & 12.186 & 4 & 3.047 & 10.044 & 0.000 \\
\hline Residual & 18.806 & 62 & 0.303 & & \\
\hline Total & 30.992 & & & & \\
\hline
\end{tabular}

Table 5. Regression output (Regression Coefficients)

\begin{tabular}{|l|l|l|l|l|l|}
\hline \multirow{2}{*}{} & \multicolumn{2}{|l|}{$\begin{array}{l}\text { Unstandardized } \\
\text { Coefficients }\end{array}$} & $\begin{array}{l}\text { Standardized } \\
\text { Coefficients }\end{array}$ & \multirow{2}{*}{ Sig. } \\
\cline { 2 - 4 } & $\mathrm{B}$ & Std. Error & Beta & & \\
\hline Intercept & -1.268 & 0.805 & & -1.575 & 0.120 \\
\hline ICT perceptions & 0.800 & 0.231 & 0.385 & 3.460 & 0.001 \\
\hline Prior Knowledge & 0.215 & 0.200 & 0.115 & 1.073 & 0.287 \\
\hline Self-efficacy & 0.400 & 0.176 & 0.256 & 2.279 & 0.026 \\
\hline Use of Mobile & 0.176 & 0.200 & 0.102 & 0.879 & 0.383 \\
\hline
\end{tabular}

